V. B. Samorodov ${ }^{1}$, Dr. Sc. (Tech.), Prof., orcid.org/0000-0002-2965-5460,

I. O. Taran ${ }^{2}$, Dr. Sc. (Tech.), Prof., orcid.org/0000-0002-3679-2519,

A. I. Bondarenko ${ }^{1}$, Dr. Sc. (Tech.), Assoc. Prof., orcid.org/0000-0001-6861-6942,

I. Yu. Klymenko, orcid.org/0000-0002-6263-0951
1 - National Technical University "Kharkiv Polytechnic Institute”, Kharkiv, Ukraine, e-mail: samorodovvadimat@gmail.com 2 - Dnipro University of Technology, Dnipro, Ukraine, e-mail: taran7077@gmail.com

\title{
COMPARATIVE ANALYSIS OF TRANSMISSIONS OF MINE DIESEL LOCOMOTIVES WITH DIFFERENT COMPONENT SCHEMES
}

Purpose. To develop mathematical models and techniques to model stepless transmissions operating as a part of a diesel locomotive, to improve reliability of the results of diesel locomotive movement under actual operating conditions.

Methodology. Values of kinematic parameters, power parameters, and energy parameters are identified with the help of solving a system of algebraic equations by Simulink subsystem of Matlab system. Integrated study of changes in basic transmission parameters of "input differential" and "output differential" in terms of its operation within both transport and traction ranges is necessary to determine the initial data to model braking process of a mine diesel locomotive.

Findings. The paper has performed comparative analysis of "input differential" and "output differential" hydrostatic mechanical transmissions (HMTs) by means of integrated study of changes in power parameters, kinematic parameters, and energy parameters of the transmissions in terms of traction and transport ranges of motion of a mine diesel locomotive. Values of these parameters are determined by means of solving the system of algebraic equations being considered as the development of a set of mathematical models and techniques to model stepless transmissions operating as a part of a mine diesel locomotive.

Originality. The obtained results of integrated study of changes in power, kinematic and energy parameters of "input differential" and "output differential" HMTs in terms of their operation within both transport and traction ranges indicate that each transmission has its own strengths and weaknesses. That is why the both HMTs will be used in future while analyzing a braking process of a mine diesel locomotive.

Practical value. The developed structural transmission scheme, mathematical model explaining changes in kinematic parameters and power ones, determined kinematic, power parameters and efficiency of hydrostatic drive in future can be applied as the initial data to model a braking process of a mine diesel locomotive.

Keywords: mine diesel locomotive, hydrostatic mechanical transmissions, differential, braking process, mathematical model

Introduction. Effectiveness of machine-building enterprises, progress of modern traction and transport equipment [1, 2], and its competitive growth in the context of world economic crisis depend greatly on the development of advanced equipment models [3]. Improved efficiency of rail transport operation in mines is a result of use of modern diesel locomotives equipped with hydrostatic mechanical transmissions (HMTs) $[4,5]$. However, acceleration of mine trains driven by diesel locomotives aggravates a problem of safety in terms of braking mode. Therefore, it involves the necessity to upgrade available transmissions and develop advanced ones for home diesel locomotives basing upon progress of computation and theoretical techniques to analyze "engine-transmission-diesel locomotive" system in terms of braking mode [6].

Literature review. It is common knowledge that only locomotives of mine trains are equipped with braking devices. That is why masses of the trains are frequently limited by their braking capabilities. Currently it is impossible to equip mine cars with technologically advanced brakes; moreover, the process involves huge capital input. In this context critical braking capabilities of diesel locomotive are its rather important parameter as they often determine and limit a range of mine locomotive transport use. Despite the fact that HMTs are very popular in the context of modern machine building (it mainly concerns tractors and military equipment) such transmissions need further thorough analysis required to specify those design parameters providing the improvement of both braking characteristics and operational characteristics of a diesel locomotive.

HMT is a hybrid transmission combining stepless velocity performance of traditional hydraulic transmission [7] and high efficiency of mechanical transmission [8]. Double-flow stepless HMTs differ significantly from the stepped mechanical and other transmissions in the fact that losses within hydro-

(c) Samorodov V. B., Taran I. O., Bondarenko A. I., Klymenko I.Yu., 2019 static drive (HD), and its efficiency depend heavily upon operation transmission mode which effects power flow value [9]. Power circulation within the double-flow transmissions formulates a problem concerning determination of power flow distribution over the closed HMT contour during mine locomotive braking since it restricts both structure of the transmission and its kinematic scheme.

Early research, intended to model hydrostatic transmissions with continuous variable power, has represented nonlinear simulation models describing a pump with variable displacement and the fixed displacement motor taking into consideration leakage losses [10] as well as linear models for adaptive control concepts [11]. Subsequently, to determine values of inlet transmission velocity as well as vehicle velocity, K. Huhtala developed a nonlinear transmission model with loss models in a steady state for both machines - a pump with variable displacement, and engine.

Paper [12] performs system simulation of hydromechanical transmissions. Moreover, it has developed a functional dynamic transmission model with separation of power flows for a tractor. The authors of [13] have designed and modeled hydrostatic continuous variable transmission with power separation for heavy-capacity vehicles. Operational problems, identified while modeling transmission dynamics, have become the most interesting of their findings.

Hydraulic hybrid system of Cumulo series for urban buses is the early example for road vehicles [14]. Exclusively for wheel loaders, the authors of [15] represented multimode hydrostatic mechanical transmission with power separation whose fuel saving is at least by $15 \%$ more than high fuel saving potential to compare with the available solution with hydraulic converter. Paper [16] lists similar results.

It is known $[17,18]$ that HMT designs have a tendency to reduce the number of frictional multidisk clutches, braking mechanisms, the number of subranges and complicated mechanical 
parts. Moreover, it has not been determined yet what HMT schemes are expedient: either "input differential" or "output differential". That is why the paper considers both alternatives.

The majority of analyzed papers describing advanced HMT designs propose either too complicated transmission structures (to be in contrast with demand for the decrease in the number of multidisk clutches and braking mechanisms) or transmissions whose efficiency is not higher than 0.8 .

Papers $[19,20]$ propose advanced "input differential" and "output differential" HMTs adapted for mine diesel locomotives whose maximum efficiency declared is 0.85 to 0.9 depending upon movement range and rolling resistance force. These very transmissions are considered as a mathematical modeling object by the paper.

Accuracy of kinematic parameters, power parameters, and energy parameters of HMT of different structures resulting from braking process modeling depends heavily on the selected initial data. The initial data of angular velocities of parts of components of transmission and working pressure difference in HD are those data which HMT components had when mine diesel locomotives were transferred from acceleration mode or uniform movement mode to braking mode.

The purpose of the research is to develop mathematical models and techniques to model stepless transmissions operating as a part of a diesel locomotive, to improve reliability of the results of diesel locomotive movement under actual operating conditions. Achievement of the objective involves: the development of a structural transmission scheme; the development of a mathematical model explaining changes in kinematic parameters and power ones; the determination of kinematic parameters and power ones as well as calculation of HD efficiency. In future the results will be applied as the initial data to model a process of mine diesel locomotive braking.

Results. As the main objective of the research is not the study of transients within transmission components in the process of transition from the acceleration mode to the braking one, initial data for the braking process model should be determined using models explaining uniform motion of mine diesel locomotives, i.e. the forces of motion resistance and air resistance are neglected taking into account insignificant value of the latter one (maximum velocity of a mine diesel locomotive considered in the paper is not more than $20 \mathrm{~km} / \mathrm{h}$ ).

As it has been mentioned before, HMT 1 (with input differential, Fig. 1) and HMT 2 (with output differential, Fig. 2) are the most potential from the viewpoint of the design simplicity and efficiency value $[19,20]$. The proposed transmissions are meant to be used for mine diesel locomotives where mass is 10 tons, wheel radius is $0.3 \mathrm{~m}$, maximum motion velocity is $10 \mathrm{~km} / \mathrm{h}$ in terms of traction range, and $20 \mathrm{~km} / \mathrm{h}$ in terms of transport range.

Despite the fact that papers $[19,20]$ propose use of hydraulic machines with 70 cubic $\mathrm{cm}$ working volume for the HMT 2 scheme, we consider controlled hydraulic pump and hydraulic motor with 90 cubic $\mathrm{cm}$ working volume each (similar to those for HMT 1) to improve the transmission efficiency. Availability of identical dimensions of hydraulic machines will help make reliable evaluation of advantages and disadvantages of each HMT.

The proposed transmissions are reversible. Reverse motion is performed after an idle gear has been actuated (no one of them is available in Figs. 1 and 2). Distribution of kinematic parameters, power parameters, and energy parameters of HMT in terms of reverse motion will be analogous to that in terms of forward motion.

Basic design parameters of HMT 1 are as follows:

- drive ratios are: $i_{1}=0.808, i_{2}=1.54, i_{3}=0.57, i_{4}=0.276$, $i_{5}=0.574, i_{6}=0.206$;

- internal drive ratio of planetary gear set is: $k=-1$.

Basic design parameters of HMT 2 are as follows:

- drive ratios are: $i_{1}=0.27, i_{2}=0.21, i_{3}=0.49, i_{4}=0.206$;

- internal drive ratio of planetary gear set is: $k=-1.2$.
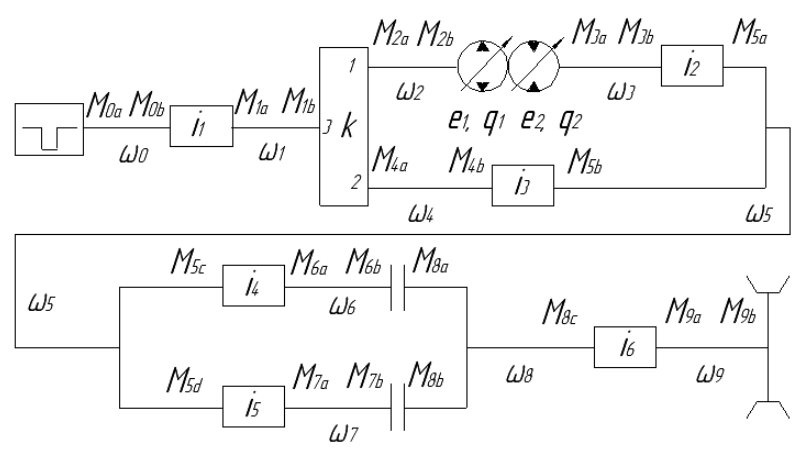

Fig. 1. Structural scheme of HMT 1 (with input differential)

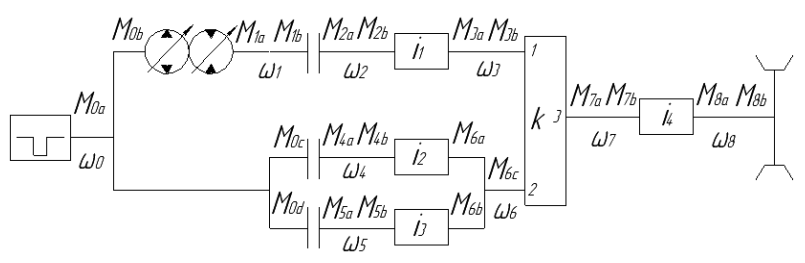

Fig. 2. Structural scheme of HMT 2(with output differential)

Paper [19] does not indicate area of power flow break within the close circuit of HMT 1; that is clutch area is not specified. Paper [6] has identified the fact that from the viewpoint of braking process dynamics, in the context of HMTs operating according to input differential scheme, it is recommended to arrange the clutch either behind the engine or within the hydraulic branch of the closed circuit in front of HD (no alternative is preferable). Consider a case when the clutch is arranged within the hydraulic branch of the close circuit in front of HD as a part of analysis of braking process of a mine diesel locomotive with HMT 1.

Relating to HMT 2, recommended area of clutch arrangement determined by paper [19] coincides completely with recommendations in paper [6]; that is, in the context of HMT with output differential (HMT 2) it is more preferable to arrange the clutch within the hydraulic branch of the closed circuit behind the HD.

As papers [19, 20] do not involve comprehensive analysis of changes in power parameters, kinematic parameters, and energy parameters of HMT, it is required to analyze changes in basic parameters of HMT 1 and HMT 2 transmissions in the context of their operation within traction range and transport range. As it has already been reported, it is necessary to determine the initial data to model braking process of a mine diesel locomotive. Values of kinematic parameters, power parameters, and energy parameters are identified with the help of solving a system of algebraic equations - expression (1) is for HMT 1 and expression (2) is for HMT 2.

The development of systems of algebraic equations involved application of models by Samorodov and Gorodetskiy as well as the known equation of Willis.

Taking into consideration specifics of the model, Simulink subsystem of Matlab system has been used to solve systems of equations $(1,2)$. General form of software implementation making it possible to solve equation system (1) is shown in Fig. 3.

Static system of algebraic equations explaining changes in power parameters, kinematic parameters, and energy parameters is:

1. For HMT 1:

Thus, equation one explains the transmission-engine relation as follows

$$
\omega_{0}=\omega_{d} .
$$

The loss moment within hydraulic machines is determined using the following expression 


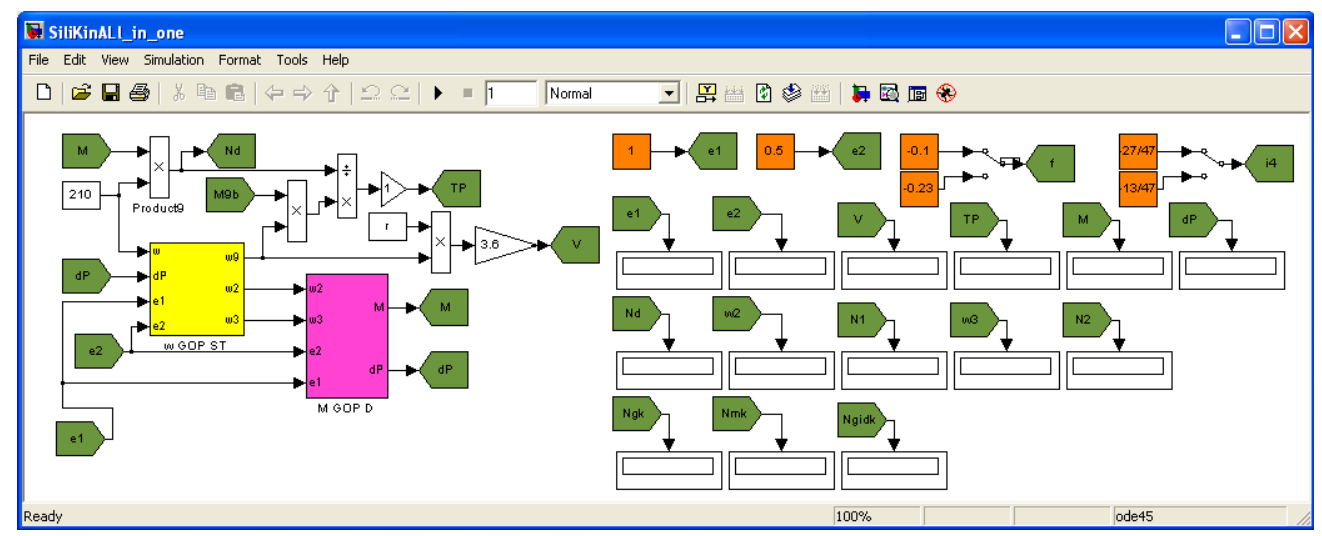

Fig. 3. General form of software implementation making it possible to solve equation system (1)

$e_{1} \cdot q_{1} \cdot \omega_{2}-e_{2} \cdot q_{2} \cdot \omega_{3}=\gamma \cdot \Delta Q+\frac{\Delta P \cdot V_{0^{*}}}{2 \cdot \pi \cdot E\left(g^{*}\right)} \cdot\left(\left|\omega_{02}\right|+\left|\omega_{03}\right|\right)$

$$
\Delta Q=\left(\frac{K_{1 y}}{\mu} \cdot\left(1+C_{1 y} \cdot\left|\omega_{02}\right|\right)+\frac{K_{2 y}}{\mu} \cdot\left(1+C_{2 y} \cdot\left|\omega_{03}\right|\right)\right) \cdot \Delta P .
$$

The total loss of working liquid within hydraulic pumps and hydraulic motor is as follows

$$
\begin{aligned}
& \Delta M_{1}=q_{1} \cdot\left[\bar{K}_{1} \cdot\left|\omega_{02}\right| \cdot\left(1+\bar{K}_{2} \cdot \bar{e}_{1}^{2}\right)+\frac{\bar{K}_{5} \cdot\left(1+\bar{K}_{4} \cdot\left|\bar{e}_{1}\right|\right)}{\left(1+\bar{K}_{3} \cdot\left|\omega_{02}\right| \cdot D_{q 1}\right)} \times\right. \\
& \left.\times \Delta P_{0}+\frac{\bar{K}_{8} \cdot\left(1+\bar{K}_{7} \cdot\left|\bar{e}_{1}\right|\right)}{\left(1+\bar{K}_{6} \cdot\left|\omega_{02}\right| \cdot D_{q 1}\right)}\right] ; \\
& D_{q 1}=\sqrt[3]{2 \cdot \pi \cdot q_{1}} ; \quad M_{3 a}+e_{2} \cdot q_{2} \cdot \Delta P=-\Delta M_{2} \cdot \operatorname{sign}\left(\omega_{03}\right) ; \\
& \Delta M_{2}=q_{2} \cdot\left[\bar{K}_{1} \cdot\left|\omega_{03}\right| \cdot\left(1+\bar{K}_{2} \cdot \bar{e}_{2}^{2}\right)+\frac{\bar{K}_{5} \cdot\left(1+\bar{K}_{4} \cdot\left|\bar{e}_{2}\right|\right)}{\left(1+\bar{K}_{3} \cdot\left|\omega_{03}\right| \cdot D_{q 2}\right)} \times\right. \\
& \left.\times \Delta P_{0}+\frac{\bar{K}_{8} \cdot\left(1+\bar{K}_{7} \cdot\left|\bar{e}_{2}\right|\right)}{\left(1+\bar{K}_{6} \cdot\left|\omega_{03}\right| \cdot D_{q 2}\right)}\right] ; \\
& D_{q 2}=\sqrt[3]{2 \cdot \pi \cdot q_{2}} ; \quad M_{3 b} \cdot \eta_{2}^{\Theta \cdot \operatorname{sign}\left(N_{3 b}\right)}+i_{2} \cdot M_{5 a}=0 .
\end{aligned}
$$

HSMT kinematics is explained with the help of a system of the following equations

$$
\begin{array}{ll}
\omega_{0} \cdot i_{1}-\omega_{1}=0 ; & \omega_{2}-k \cdot \omega_{4}+(k-1) \cdot \omega_{1}=0 \\
\omega_{3} \cdot i_{2}-\omega_{5}=0 ; & \omega_{4} \cdot i_{3}-\omega_{5}=0 \\
\omega_{5} \cdot i_{4}-\omega_{6}=0 ; & \omega_{5} \cdot i_{5}-\omega_{7}=0 ; \\
\omega_{6}-\omega_{8}=0 ; & Y=1 ; \\
\omega_{7}-\omega_{8}=0 ; & Y=0 ; \\
\omega_{8} \cdot i_{6}-\omega_{9}=0 . &
\end{array}
$$

Power transmission parameters can be described using the following equations

$$
\begin{gathered}
M_{0 b} \cdot \eta_{1}^{\Theta \cdot \operatorname{sign}\left(N_{0 b}\right)}+i_{1} \cdot M_{1 a}=0 ; \\
M_{2 a} \cdot \eta_{13}^{\Theta \cdot \operatorname{sign}\left(N_{2 a}\right)}+M_{4 a} \cdot \eta_{23}^{\Theta} \cdot \operatorname{sign}\left(N_{4 a}\right)+M_{1 b}=0 ; \\
M_{2 a} \cdot k \cdot \eta_{13}^{\Theta} \cdot \operatorname{sign}\left(N_{2 a}\right)+M_{4 a} \cdot \eta_{23}^{\Theta \cdot \operatorname{sign}\left(N_{4 a}\right)}=0 ; \\
M_{2 b}-e_{1} \cdot q_{1} \cdot \Delta P=-\Delta M_{1} \cdot \operatorname{sign}\left(\omega_{02}\right) ; \\
M_{4 b} \cdot \eta_{3}^{\Theta \cdot \operatorname{sign}\left(N_{4 b}\right)}+i_{3} \cdot M_{5 b}=0 ; \\
M_{5 c} \cdot \eta_{4}^{\Theta \cdot \operatorname{sign}\left(N_{5 c}\right)}+i_{4} \cdot M_{6 a}=0 ; \\
M_{6 b}+M_{8 a}=0, \quad Y=1 ; \quad M_{7 b}=M_{8 b}=0, \quad Y=1 ; \\
M_{5 d} \cdot \eta_{5}^{\Theta \cdot \operatorname{sign}\left(N_{5 d}\right)}+i_{5} \cdot M_{7 a}=0 ; \\
M_{7 b}+M_{8 b}=0, \quad Y=0 ; \quad M_{6 b}=M_{8 a}=0, \quad Y=0 ;
\end{gathered}
$$

$$
\begin{gathered}
M_{8 c} \cdot \eta_{6}^{\Theta \cdot \operatorname{sign}\left(N_{8 c}\right)}+i_{6} \cdot M_{9 a}=0 ; \\
M_{9 b}-G \cdot f \cdot r=0 ; M_{0 a}+M_{0 b}=0 ; \\
M_{1 a}+M_{1 b}=0 ; \quad M_{2 a}+M_{2 b}=0 ; \\
M_{3 a}+M_{3 b}=0 ; \quad M_{4 a}+M_{4 b}=0 ; \\
M_{5 a}+M_{5 b}+M_{5 c}+M_{5 d}=0 ; \\
M_{6 a}+M_{6 b}=0 ; \quad M_{7 a}+M_{7 b}=0 ; \\
M_{8 a}+M_{8 b}+M_{8 c}=0 ; \quad M_{9 a}+M_{9 b}=0 .
\end{gathered}
$$

\section{For HMT 2:}

Thus, equation one explains the transmission-engine relation as follows

$$
\omega_{0}=\omega_{d}
$$

The loss moment within hydraulic machines is determined using the following expression

$$
\begin{gathered}
e_{1} \cdot q_{1} \cdot \omega_{0}-e_{2} \cdot q_{2} \cdot \omega_{1}=\gamma \cdot \Delta Q+\frac{\Delta P \cdot V_{0^{*}}}{2 \cdot \pi \cdot E\left(g^{*}\right)} \cdot\left(\left|\omega_{00}\right|+\left|\omega_{01}\right|\right) ; \\
\Delta Q=\left(\frac{K_{1 y}}{\mu} \cdot\left(1+C_{1 y} \cdot\left|\omega_{00}\right|\right)+\frac{K_{2 y}}{\mu} \cdot\left(1+C_{2 y} \cdot\left|\omega_{01}\right|\right)\right) \cdot \Delta P .
\end{gathered}
$$

The total loss of working liquid within hydraulic pumps and hydraulic motor is as follows

$$
\begin{aligned}
& \Delta M_{1}=q_{1} \cdot\left[\bar{K}_{1} \cdot\left|\omega_{00}\right| \cdot\left(1+\bar{K}_{2} \cdot \bar{e}_{1}^{2}\right)+\frac{\bar{K}_{5} \cdot\left(1+\bar{K}_{4} \cdot\left|\bar{e}_{1}\right|\right)}{\left(1+\bar{K}_{3} \cdot\left|\omega_{00}\right| \cdot D_{q 1}\right)} \times\right. \\
& \left.\times \Delta P_{0}+\frac{\bar{K}_{8} \cdot\left(1+\bar{K}_{7} \cdot\left|\bar{e}_{1}\right|\right)}{\left(1+\bar{K}_{6} \cdot\left|\omega_{00}\right| \cdot D_{q 1}\right)}\right] ; \\
& D_{q 1}=\sqrt[3]{2 \cdot \pi \cdot q_{1}} ; \quad M_{1 a}+e_{2} \cdot q_{2} \cdot \Delta P=-\Delta M_{2} \cdot \operatorname{sign}\left(\omega_{01}\right) ; \\
& \Delta M_{2}=q_{2} \cdot\left[\bar{K}_{1} \cdot\left|\omega_{01}\right| \cdot\left(1+\bar{K}_{2} \cdot \bar{e}_{2}^{2}\right)+\frac{\bar{K}_{5} \cdot\left(1+\bar{K}_{4} \cdot\left|\bar{e}_{2}\right|\right)}{\left(1+\bar{K}_{3} \cdot\left|\omega_{01}\right| \cdot D_{q 2}\right)} \times\right. \\
& \times \Delta P_{0}+\frac{\bar{K}_{8} \cdot\left(1+\bar{K}_{7} \cdot\left|\bar{e}_{2}\right|\right)}{\left(1+\bar{K}_{6} \cdot\left|\omega_{01}\right| \cdot D_{q 2}\right)} ; \text {; } \\
& D_{q 2}=\sqrt[3]{2 \cdot \pi \cdot q_{2}} ; \quad M_{1 b}+M_{2 a}=0 .
\end{aligned}
$$

HSMT kinematics is explained with the help of a system of the following equations

$$
\begin{gathered}
\omega_{1}-\omega_{2}=0 ; \quad \omega_{2} \cdot i_{1}-\omega_{3}=0 ; \\
\omega_{0}-\omega_{4}=0, \quad Y=1 ; \quad \omega_{4} \cdot i_{2}-\omega_{6}=0 ; \\
\omega_{0}-\omega_{5}=0, \quad Y=0 ; \quad \omega_{5} \cdot i_{3}-\omega_{6}=0 ; \\
\omega_{3}-k \cdot \omega_{6}+(k-1) \cdot \omega_{7}=0 ; \quad \omega_{7} \cdot i_{4}-\omega_{8}=0 .
\end{gathered}
$$


Power transmission parameters can be described using the following equations

$$
\begin{aligned}
& M_{0 b}-e_{1} \cdot q_{1} \cdot \Delta P=-\Delta M_{1} \cdot \operatorname{sign}\left(\omega_{00}\right) ; \\
& M_{2 b} \cdot \eta_{1}^{\Theta \cdot \operatorname{sign}\left(N_{2 b}\right)}+i_{1} \cdot M_{3 a}=0 ; \\
& M_{0 c}+M_{4 a}=0, \quad Y=1 ; \quad M_{0 d}=M_{5 a}=0, \quad Y=1 ; \\
& M_{4 b} \cdot \eta_{2}^{\Theta \cdot \operatorname{sign}\left(N_{4 b}\right)}+i_{2} \cdot M_{6 a}=0 \text {; } \\
& M_{0 d}+M_{5 a}=0, \quad Y=0 ; \quad M_{0 c}=M_{4 a}=0, \quad Y=0 ; \\
& M_{5 b} \cdot \eta_{3}^{\Theta \cdot \operatorname{sign}\left(N_{5 b}\right)}+i_{3} \cdot M_{6 b}=0 \text {; } \\
& M_{3 b} \cdot \eta_{13}^{\Theta \cdot \operatorname{sign}\left(N_{3 b}\right)}+M_{6 c} \cdot \eta_{23}^{\Theta \cdot \operatorname{sign}\left(N_{6 c}\right)}+M_{7 a}=0 ; \\
& M_{3 b} \cdot k \cdot \eta_{13}^{\Theta \cdot \operatorname{sign}\left(N_{3 b}\right)}+M_{6 c} \cdot \eta_{23}^{\Theta \cdot \operatorname{sign}\left(N_{6 c}\right)}=0 ; \\
& M_{7 b} \cdot \eta_{4}^{\Theta \cdot \operatorname{sign}\left(N_{7 b}\right)}+i_{4} \cdot M_{8 a}=0 \text {; } \\
& M_{8 b}-G \cdot f \cdot r=0 ; \\
& M_{0 \tilde{a}}+M_{0 \tilde{b}}+M_{0}+M_{0}=0 \text {; } \\
& M_{1 a}+M_{1 b}=0 ; \quad M_{2 a}+M_{2 b}=0 ; \\
& M_{3 a}+M_{3 b}=0 ; \quad M_{4 a}+M_{4 b}=0 ; \\
& M_{5 a}+M_{5 b}=0 ; \quad M_{6 a}+M_{6 b}+M_{6 c}=0 ; \\
& M_{7 a}+M_{7 b}=0 ; \quad M_{8 a}+M_{8 b}=0,
\end{aligned}
$$

where $\omega_{i}$ is the angular velocity of transmission segment; $\omega_{d}$ is the angular velocity of engine crankshaft; $i_{j}$ is transmission ratio; $k$ is internal drive ratio of planetary gear set; $e_{1}, e_{2}$ are parameters to control HD hydraulic machines; $q_{1}, q_{2}$ are maximum efficiency of hydraulic machines; $\gamma$ is the coefficient characterizing power flow direction $(\gamma=1$ is straight power flow; $\gamma=-1$ is reverse power flow); $\Delta Q$ is hydraulic liquid leakage in all hydraulic machines involving symbol of pressure difference in $\mathrm{HD} ; \Delta P$ is working pressure difference in $\mathrm{HD} ; V_{0^{*}}$ is the volume of liquid being compressed; $E\left(g^{*}\right)$ is module of working liquid tension depending on gas content percentage $g^{*} ; \omega_{02}, \omega_{00}$ are angular velocities of hydraulic pump shaft $\left(\omega_{02}\right.$ corresponds to the input differential HMT scheme; $\omega_{00}$ corresponds to the output differential HMT scheme) calculated in the process of iteration solution of non-linear matrix system during previous iteration being considered as that equal to 0 for iteration one; $\omega_{03}, \omega_{01}$ are angular velocities of hydraulic motor shaft $\left(\omega_{03}\right.$ corresponds to the input differential HMT scheme; $\omega_{01}$ corresponds to the output differential HMT scheme) calculated in the process of iteration solution of the non-linear matrix system during previous iteration being considered as that equal to 0 for iteration one; $K_{i y}, C_{i y}$ are coefficients of losses for the hydraulic pump $(i=1)$ and hydraulic motor $(i=2)$; $\mu$ is the coefficient of dynamic viscosity; $Y$ is the coefficient characterizing the range of motion $(Y=1$ is traction range, $Y=0$ is transport range); $M_{n m}$ are moments within HMT components; $m$ are indices corresponding to the number of angular velocity of the component; $n$ are indices-letters corresponding to moments at the ends of the components; $n_{j}$ is efficiency of the gear; $\Theta$ is the coefficient considering losses within gear clutches $(\Theta=0$ is the coefficient ignoring losses; $\Theta=-1$ is the coefficient considering the losses); $N_{n m}$ is power transmitted by HMT components; $\eta_{13}, \eta_{23}$ are efficiencies within sun-pinion and epicycle-planet gear clutches when the carrier is stopped determining losses of moments; $\Delta M_{1}, \Delta M_{2}$ are losses of a moment within hydraulic machines [6]; $\bar{K}_{1}, \bar{K}_{2}, \ldots, \bar{K}_{8}$ are coefficients of hydromechanical losses; $D_{q i}$ is typical dimension of hydraulic machines; $\Delta P_{0}$ is working pressure difference within HD calculated in the process of iteration solution of the nonlinear matrix system during previous iteration being considered as that equal to 0 for iteration one; $G$ is weight of a mine diesel locomotive; $r$ is the radius of wheels; $f$ is resistance to the motion coefficient.

Certain results of theoretical studies of HMT 1 and HMT 2 are shown in Figs. 4 and 5 where: $V$ is the velocity of a mine

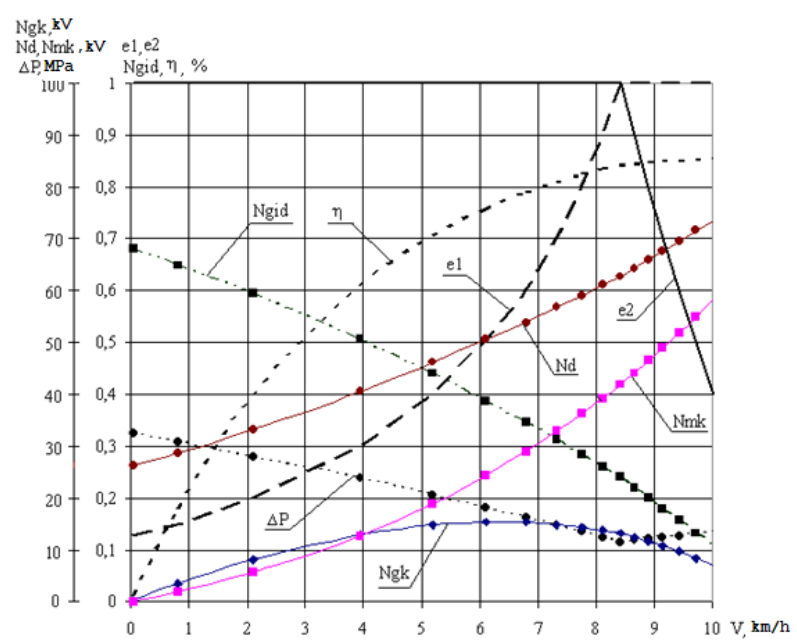

Fig. 4. Results of theoretical analysis of HMT 1 within the traction range of a mine diesel locomotive motion

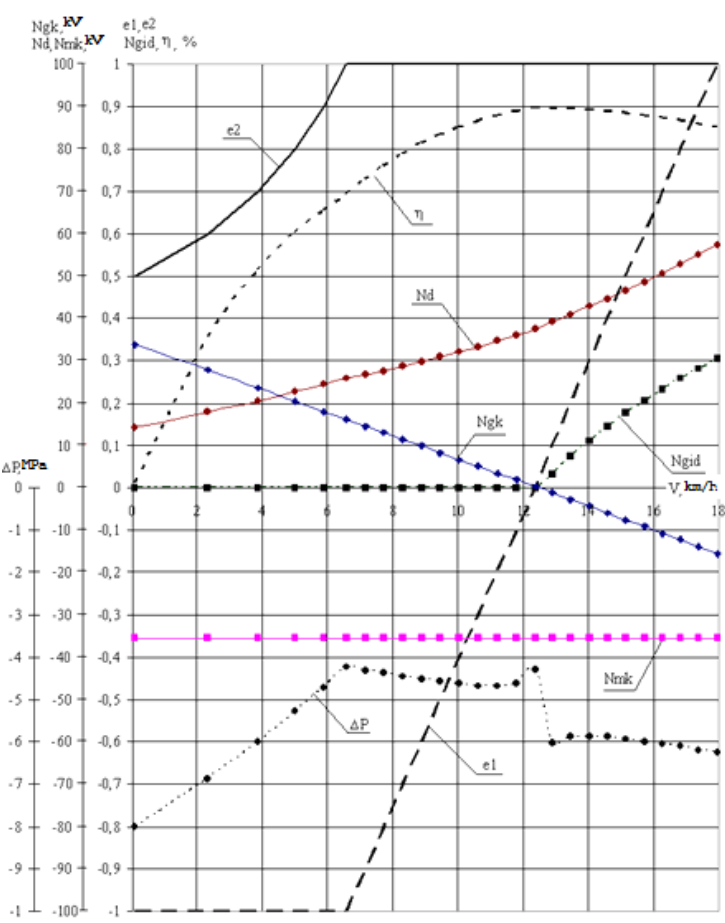

Fig. 5. Results of theoretical analysis of HMT 2 within the transport range of a mine diesel locomotive motion

diesel locomotive; $\eta$ is efficiency of transmission; $M$ is torque effect within a shaft of crankshaft; $N_{d}$ is engine capacity; $N_{1}$ is the power entering HD; $N_{2}$ is the power leaving HD; $N_{g k}$ is the power leaving hydraulic branch of the closed circuit of HMT; $N_{m k}$ is the power leaving mechanical branch of the closed circuit of HMT; $N_{\text {gid }}$ is percentage ratio of the power being transmitted through the hydraulic branch to the power outgoing from the closed circuit.

Static analysis of HMT 1 and HMT 2 has helped determine the following:

\section{Advantages of HMT 1:}

- maximum velocity of mine diesel locomotives within the transport range in terms of HMT1 use is $2.0 \%$ higher to compare with HMT 2 use (HMT 1 is $20 \mathrm{~km} / \mathrm{h}$ and HMT 2 is $18 \mathrm{~km} / \mathrm{h}$ );

- maximum value of angular velocity of a shaft of hydraulic motor of HMT 1 is 1.8 times less comparing with HMT 2 in terms of motion within the traction range $(-105.80 \mathrm{rad} / \mathrm{s}$ is for HMT1 and $-192.70 \mathrm{rad} / \mathrm{s}$ is for HMT 2) 
and 4.5 times less in terms of motion within the transport range $(-102.90 \mathrm{rad} / \mathrm{s}$ is for HMT 1 and $-455.10 \mathrm{rad} / \mathrm{s}$ is for HMT 2; modern hydraulic machines "PSM-HYDRAYLIKS" of the selected size withstand angular velocity up to $460.0 \mathrm{rad} / \mathrm{s}$ ):

- lack of power circulation (in terms of the closed circuit of HMT 2 when a mine diesel locomotive accelerates from zero velocity up to the velocity corresponding to $e_{1}=0.1$ value; in this context power circulation with overloading of mechanical branch of transmission takes place).

\section{Advantages of HMT 2:}

- maximum efficiency value of HMT 1 is by $2.0 \%$ less to compare with HMT 2 in terms of motion within the traction range ( 0.853 is for HMT 1 and 0.870 is for HMT 2$)$ and by $5.1 \%$ less in terms of motion within the transportation range ( 0.853 is for HMT 1 and 0.899 is for HMT 2);

maximum working pressure difference within $\mathrm{HD}$ of HMT 1 is 2.9 times more compared to HMT 2 in terms of motion within the traction range $(32.41 \mathrm{MPa}$ is for HMT 1 and $-13.24 \mathrm{MPa}$ is for HMT 2) and 3.7 times more in terms of motion within the transport range (29.89 MPa is for HMT 1 and $-8.01 \mathrm{MPa}$ is for HMT 2; modern hydraulic machines "PSMHYDRAYLIKS" of the selected size withstand working pressure difference up to $40.0 \mathrm{MPa}$ );

- maximum value of the angular velocity of shaft of HMT 1 hydraulic pump is 1.6 times more compared to HMT 2 both in terms of motion within the traction range $(-337.90 \mathrm{rad} / \mathrm{s}$ is for HMT 1 and $210.00 \mathrm{rad} / \mathrm{s}$ is for HMT 2) and in terms of motion within the transport range (-338.90 rad/s is for HMT 1 and $210.00 \mathrm{rad} / \mathrm{s}$ is for HMT 2; modern hydraulic machines "PSM-HYDRAYLIKS" of the selected size withstand angular velocity up to $460.0 \mathrm{rad} / \mathrm{s}$ ).

Conclusions. Integrated study of changes in power parameters, kinematic parameters and energy parameters of "input differential" and "output differential" HMTs has analyzed changes in basic transmission parameters in terms of its operation within both transport and traction ranges. Values of kinematic parameters, power parameters and energy parameters have been determined by means of solving the system of algebraic equations being considered as the development of a set of mathematical models and techniques to model stepless transmissions operating as a part of a mine diesel locomotive. The peculiarity of the considered static model is the fact that the calculations involve simultaneously two values of angular velocities of shafts of hydraulic machines and working pressure difference within HD (both current pressure and previous one). That makes it possible to determine rather accurately all kinematic parameters, power parameters and energy parameters of the transmission. Each parameter is identified until a value of the parameter being under analysis at the previous iteration is equal to the current value.

Maximum velocity of a mine diesel locomotive, maximum value of angular velocity of a shaft of hydraulic motor, maximum value of HMT efficiency, maximum difference of working pressure within HD, maximum value of angular velocity of a shaft of HMT hydraulic pump as well as relation of the parameters in terms of diesel locomotive motion within traction range and transport range have been identified. As the analysis explains, each transmission has its own advantages and disadvantages. That is why the both HMTs will be used during the following analysis of braking process of mine diesel locomotives.

Power circulation with overloading of a mechanical branch of transmission takes place within the closed circuit of HMT 2 operating according to the "output differential" scheme when a mine diesel locomotive accelerates from zero velocity up to the velocity corresponding to $\mathrm{e}_{1}=0.1$ value. That is typical for the whole class of two-flow transmissions operating according to the "output differential" scheme. The fact is proved demonstratively in [5].

\section{References.}

1. Kravets, V.V., Sakhno, V.P., Bass, K. M., \& Kravets, V.I. (2018). Program spatial movement of high-speed vehicles. IOP Conference Series: Materials Science and Engineering, 383(1), 012032. DOI: 10.1088/1757-899X/383/1/012032.

2. Zabolotny, K., Zinovyev, S., Zupiev, A., \& Panchenko, E. (2015). Rationale for the parameters equipment for rope dehydration of mining hoisting installations. New Developments in Mining Engineering 2015: Theoretical and Practical Solutions of Mineral Resources Mining, 275-283.

3. Ziborov, K.A., \& Fedoriachenko, S. O. (2015). On influence of additional members' movability of mining vehicle on motion characteristics. New Developments in Mining Engineering 2015: Theoretical and Practical Solutions of Mineral Resources Mining, 237-241.

4. Macor, A., \& Rossetti, A. (2011). Optimization of Hydromechanical Power Split Transmissions. Mechanism and Machine Theory, 46(12), 1901-1919. DOI: 10.1016/j.mechmachtheory.2011.07.007.

5. Rossetti, A., Macor, A., \& Scamperle, M. (2017). Optimization of components and layouts of hydromechanical transmissions. International Journal of Fluid Power, 18(2), 123-134. DOI: $10.1080 / 14399776.2017 .1296746$.

6. Taran, I., \& Bondarenko, A. (2017). Conceptual approach to select parameters of hydrostatic and mechanical transmissions for wheel tractors designed for agrucultural opeations. Archives of transport, 41(1), 89-100. DOI: 10.5604/01.3001.0009.7389.

7. Singh, R. B., Kumar, R., \& Das, J. (2013). Hydrostatic transmission systems in heavy machinery: overview. International Journal of Mechanical and Production Engineering, 1(4(4)), 47-51.

8. Matsyuk, I. N., Shlyahov, E. M., \& Yehurnov, O. I. (2018). Some aspects of synthesis of linkage of complex structures. Naukovyi Visnyk Natsionalnoho Hirnychoho Universytetu, 3, 57-63. DOI: 10.29202/nvngu/2018-3/14.

9. Taran, I. A. (2012). Interrelation of circular transfer ratio of double-split transmissions with regulation characteristic in case of planetary gear output. Naukovyi Visnyk Natsionalnoho Hirnychoho Universytetu, 3, 75-85.

10. Rydberg, K. (2010). Hydro-mechanical Transmissions. Fluid and Mechatronic Systems, 2, 51-60.

11. Karbaschian, M.A., \& Söffker, D. (2014). Review and Comparison of Power Management Approaches for Hybrid Vehicles with Focus on Hydraulic Drives. Energies, 7, 35123536. DOI: 10.3390/en7063512.

12. Park, Y.-J., Kim, S.-Ch., \& Kim, J.-G. (2016). Analysis and verification of power transmission characteristics of the hydromechanical transmission for agricultural tractors. Journal of Mechanical Science and Technology, 30(11), 5063-5072. DOI: 10.1007/s12206-016-1056-y.

13. Hu, J., Wei, C., Yuan, S., \& Jing, C. (2009). Characteristics on hydro-mechanical transmission in power shift process. Chinese Journal of Mechanical Engineering, 22(1), 50-56.

14. Cheong, K. L., Li, P.Y., \& Chase, T.R. (2011). Optimal design of power-split transmissions for hydraulic hybrid passenger vehicles. American Control Conference. San Francisco, USA (pp. 3295-3300). June 29-July 01. DOI: 10.1109/ ACC.2011.5991509.

15. Nillson, T., Fröberg, A., \& Åslund, J. (2012). Fuel potential and prediction sensitivity of a power-split CVT in a wheel loader. Proceedings of the The International Federation of Automatic Control Rueil-Malmaison. Rueil-Malmaison, Malmaison, France (pp. 23-25).October 2012. DOI: 10.3182/20121023-3FR-4025.00017.

16. Liu, X., Sun, D., Qin, D., \& Liu, J. (2017). Achievement of Fuel Savings in Wheel Loader by Applying Hydrodynamic Mechanical Power Split Transmissions. Energies, 10, 1267. DOI: $10.3390 /$ en 10091267.

17. Jin, Y., Zhu, C., Min, C., \& Rongzhao, P. (2019). Hydromechanical power split transmissions: Progress evolution and 
future trends. Proceedings of the Institution of Mechanical Engineers, Part D: Journal of Automobile Engineering, 233(3), 727739. DOI: $10.1177 / 0954407017749734$.

18. Pettersson, K., Heybroek, K., Per Mattsson, P., \& Krus, P. (2017). A novel hydromechanical hybrid motion system for construction machines. International Journal of Fluid Power, 18(1), 17-28. DOI: 10.1080/14399776.2016.1210423.

19. Taran, I. A. (2012). Laws of power transmission on branches of double-split hydrostatic mechanical transmissions. Naukovyi Visnyk Natsionalnoho Hirnychoho Universytetu, 2, 69-75. 20. Taran, I., \& Klymenko, I. (2013). Transfer ratio of doublesplit transmissions in case of planetary gear input. Naukovyi Visnyk Natsionalnoho Hirnychoho Universytetu, 6, 60-66.

\section{Порівняльний аналіз трансмісій шахтних дизелевозів 3 різними компонувальними схемами}

\section{В. Б. Самородов ${ }^{1}$, I. О. Таран ${ }^{2}$, А. І. Бондаренко ${ }^{1}$, I. Ю. Клименко}

1 - Національний технічний університет „Харківський політехнічний інститут“, м. Харків, Україна, e-mail: samorodovvadimat@gmail.com

2 - Національний технічний університет „Дніпровська політехніка“, м. Дніпро, Україна, e-mail: $\underline{\operatorname{taran} 7077 @}$ gmail.com

Мета. Розробка комплексу математичних моделей і методик моделювання безступінчастих трансмісій, що працюють у складі дизелевоза, для підвищення достовірності результатів аналізу руху дизелевоза в реальних умовах експлуатації.

Методика. Значення кінематичних, силових і енергетичних параметрів визначаються шляхом розв'язання системи алгебраїчних рівнянь з використанням підсистеми Simulink системи Matlab. Комплексне дослідження зміни основних параметрів трансмісій „з диференціалом на вході““ та „з диференціалом на виході““ при їх роботі на транспортному й тяговому діапазонах необхідно для визначення вихідних даних для моделювання процесу гальмування шахтного дизелевоза.

Результати. У роботі виконано порівняльний аналіз гідрооб'ємно-механічних трансмісій (ГОМТ) „з диференціалом на вході““ та „з диференціалом на виході““ шляхом комплексного дослідження зміни силових, кінематичних і енергетичних параметрів трансмісій при роботі на тяговому та транспортному діапазонах руху шахтного дизелевоза. Значення цих параметрів визначені шляхом розв'язання складеної системи алгебраїчних рівнянь, що розцінюється як розвиток комплексу математичних моделей і методик моделювання безступінчастих трансмісій, що працюють у складі дизелевоза.

Наукова новизна. Отримані результати комплексного дослідження зміни силових, кінематичних і енергетичних параметрів ГОМТ „з диференціалом на вході“ та „з диференціалом на виході“ при роботі на транспортному й тяговому діапазонах свідчать про те, що кожна трансмісія має свої переваги й недоліки. Саме тому обидві ГОМТ будуть використовуватися в подальшому при дослідженні процесу гальмування шахтних дизелевозів.

Практична значимість. Розроблена структурна схема трансмісії, математична модель, що описує зміну кінематичних і силових параметрів, а також обчислені кінематичні, силові параметри та ККД гідрооб'ємної передачі в подальшому можуть буди використані як вихідні дані для моделювання процесу гальмування шахтного дизелевоза.
Ключові слова: шахтний дизелевоз, гідрооб'ємномеханічна трансмісія, диференціал, процес гальмування, математична модель

\section{Сравнительный анализ трансмиссий шахтных дизелевозов с различными компоновочными схемами}

\section{В. Б. Самородов ${ }^{1}$, И. А. Таран ${ }^{2}$, А. И. Бондаренко ${ }^{1}$, И. Ю. Клименко}

1 - Национальный технический университет „Харьковський политехнический институт“, г. Харьков, Украина, e-mail: samorodovvadimat@gmail.com

2 - Национальный технический университет „Днепров-

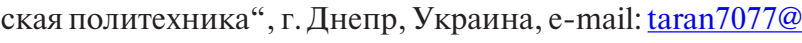
gmail.com

Цель. Разработка комплекса математических моделей и методик моделирования бесступенчатых трансмиссий, работающих в составе дизелевоза, для повышения достоверности результатов анализа движения дизелевоза в реальных условиях эксплуатации.

Методика. Значения кинематических, силовых и энергетических параметров определяются путем решения системы алгебраических уравнений с использованием подсистемы Simulink системы Matlab. Комплексное исследование изменения основных параметров трансмиссий „с дифференциалом на входе“ и „с дифференциалом на выходе“ при их работе на транспортном и тяговом диапазонах необходимо для определения исходных данных для моделирования процесса торможения шахтного дизелевоза.

Результаты. В работе выполнен сравнительный анализ гидрообъемно-механических трансмиссий (ГОМТ) „с дифференциалом на входе“ и „с дифференциалом на выходе“ путем комплексного исследования изменения силовых, кинематических и энергетических параметров трансмиссий при работе на тяговом и транспортном диапазонах движения шахтного дизелевоза. Значения этих параметров определены путем решения составленной системы алгебраических уравнений, что расценивается как развитие комплекса математических моделей и методик моделирования бесступенчатых трансмиссий, работающих в составе дизелевоза.

Научная новизна. Полученные результаты комплексного исследования изменения силовых, кинематических и энергетических параметров ГОМТ „с дифференциалом на входе“ и „с дифференциалом на выходе“ при их работе на транспортном и тяговом диапазонах свидетельствуют о том, что каждая трансмиссия имеет свои преимущества и недостатки. Именно поэтому обе ГОМТ будут использоваться в дальнейшем при исследовании процесса торможения шахтных дизелевозов.

Практическая значимость. Разработанная структурная схема трансмиссии, математическая модель, описывающая изменение кинематических и силовых параметров, а также определенные кинематические, силовые параметры и КПД гидрообъемной передачи в дальнейшем могут быть использованы как исходные данные для моделирования процесса торможения шахтного дизелевоза.

Ключевые слова: шахтный дизелевоз, гидрообъемно-механическая трансмиссия, дифференциал, процесс торможения, математическая модель

Рекомендовано до публікаиії докт. техн. наук B. I. Самусею. Дата надходження рукопису 12.02.19. 